\title{
A review of the infection-associated cancers in North African countries
}

\author{
Wafaa Mohamed Hussein ${ }^{1}$, Wagida A. Anwar ${ }^{1}$, Mohammed Attaleb², Loubna Mazini ${ }^{3}$, Asta Försti' ${ }^{4,5}$, \\ Roxana-Delia Trimbitas ${ }^{3}$ and Meriem Khyatti ${ }^{3^{*}}$ (i)
}

\begin{abstract}
Cancer is typically classified as a leading non-communicable disease; however, infectious agents, such as Helicobacter pylori (H. pylori), hepatitis B virus ( $\mathrm{HBV}$ ), hepatitis C virus ( $\mathrm{HCV}$ ) and human papilloma virus (HPV), contribute significantly to the pathogenesis of various cancers. Less developed countries, including countries of the North African (NA) region, endure the highest burden of infection-related cancers. The five most common infection-associated cancers in NA in order of incidence are bladder cancer, cervical cancer, liver cancer, stomach cancer, and nasopharyngeal carcinoma. This review aims to outline the epidemiologic pattern of infection-associated cancers in five NA countries (namely: Morocco, Algeria, Tunisia, Libya and Egypt) highlighting the similarities and differences across the region. The present study employed an initial literature review of peer-reviewed articles selected from PubMed, ScienceDirect and World Health Organization (WHO) databases based on key word searches without restriction on publication dates. Original research articles and reports written in French, as well as data from institutional reports and regional meeting abstracts were also included in this extensive review. Egypt, Libya, Tunisia, Algeria and Morocco were selected to be the focus of this review.
\end{abstract}

Keywords: Infection, Cancer, North Africa

\section{Background}

Cancer is typically classified as a non-communicable disease; however, infectious agents contribute significantly to cancer etiology [1]. The International Agency for Research on Cancer (IARC) has labelled some infectious agents as carcinogens, these include; Helicobacter pylori (H. pylori), hepatitis B virus (HBV), hepatitis C virus (HCV), Opisthorchis viverrini, Clonorchis sinensis, human papillomavirus (HPV), Epstein-Barr virus (EBV), human T-cell lymphotropic virus type 1 (HTLV-1), human herpes virus type 8 (HHV-8, also known as Kaposi's sarcoma herpes virus; KSHV) and Schistosoma haematobium (S. haematobium) [2]. The data consistently point to an association between an infectious agent and a specific malignancy and ranges from $100 \%$ (e.g. cervical cancer (CC) attributable to HPV) to $0.4 \%$ (liver cancer caused by liver flukes), depending on the infectious agent, the cancer and the geographical location [3]. Persistent infection with certain types of HPV has been established as a necessary cause for $\mathrm{CC}$, accounting for

\footnotetext{
* Correspondence: meriem.khyatti@pasteur.ma

${ }^{3}$ Laboratory of Onco-virology, Institut Pasteur du Maroc, Casablanca, Morocco Full list of author information is available at the end of the article
}

$100 \%$ of these tumors. In addition to CC, oncogenic HPVs were found in approximately $88 \%$ of anal cancers, $70 \%$ of vaginal cancers, $50 \%$ of penile cancers, and $43 \%$ of vulvar cancers. Among other cancer types, HHV-8 has been found in nearly all tumors in patients with Kaposi's sarcoma (KS). In endemic areas, all squamous cell carcinomas (SCCs) are assumed be attributed to schistosomiasis. H. pylori infection is consistently associated with gastric carcinoma and all nasopharyngeal carcinoma (NPC) cases are associated with EBV infection, while T-cell leukemia is rare in HTLV-1 negative subjects. Overall, $75 \%$ to $80 \%$ of cases of primary liver cancers are attributable to persistent infections with either HBV (50-55 \%) or HCV (25-30 \%) [1].

Malignant transformations of human cells that may be caused by infectious agents occur through different mechanisms of action [4]. These agents may act as direct carcinogens through the expression of oncogenes. The resulting onco-proteins can interact with cellular proteins leading to disruption of cell-cycle check-points, inhibition of apoptosis, and enhancement of cell immortalization. Infectious agents, such as HPV, HBV, HTLV-1, EBV and $\mathrm{KSHV}$, act through this mechanism. Another mechanism 
of malignant transformation occurs as follows: chronic infection followed by chronic inflammation leads to the release of inflammatory mediators and the production of free oxygen radicals, which have direct mutagenic effects in addition to promoting tumor neo-vascularization and survival. Inflammation-induced cancers are associated with $\mathrm{HCV}, H$. pylori and $S$. haematobium. Immunesuppression induced by human immunodeficiency virus (HIV-1), as well as KSHV and EBV, strongly increases the incidence of many other infection-associated cancers.

A systematic analysis by de Martel et al. from 2012 estimated that $16.1 \%$ (about 2 million) of all new cancer cases reported during 2008, were directly attributable to infections; the majority of which ( $80 \%, 1.6$ million) originated in less developed countries. The proportion of infection-associated cancers ranged between $7.4 \%$ and $22.9 \%$ in developed and developing countries, respectively. According to the same study, in North African (NA) region the proportion was estimated at $12.7 \%$, with local variations between and within countries $[1,5]$.

Hepatitis B and C, HPV, and H. Pylori have been associated with about $95 \%$ of infection-associated cancer cases. Cancer sites affected include cancers of the liver, cervix, selected head and neck cancers, and gastric cancers. These viruses differ in their contribution to cancer burden worldwide. HPV contributes equally to the cancer burden in both developed and developing countries. H. Pylori results in more cancer cases in developed countries, while $\mathrm{HCV}$ and $\mathrm{HBV}$ result in higher cancer rates in developing countries [6]. In NA, the five most common infection-related cancers in descending order are: bladder cancer, cervical cancer, liver cancer, stomach cancer, and NPC (Table 1). This review aims to demonstrate the influence of infectious agents on cancer pattern in NA countries and to summarize and provide up-to-date data in a region-specific manner.

\section{Methods}

The present study employed an initial literature review of peer-reviewed articles published in PubMed, ScienceDirect, and World Health Organization (WHO) databases with no restriction on publication date. Original research articles and reports written in French, as well as data from institutional reports and regional meeting abstracts were also included in this extensive review. In the articles and reports, data in the NA countries (Egypt, Libya, Tunisia, Algeria and Morocco) were considered eligible when the nature of epidemiological data, such as prevalence and incidence rates, were specified. Combinations of keywords used in the searches were: infectious agents (EBV, HCV, HBV, schistosomiasis, HPV, H. Pylori, HHV-8 and HTLV-1); country name (Egypt, Algeria, Morocco, Tunisia, Libya, NA and Maghreb); cancer type (bladder, cervical, liver, hepatocellular carcinoma (HCC), anogenital, and NPC).

\section{Schistosomiasis and bladder cancer}

Bladder cancer is the 11th most common cancer worldwide, affecting predominantly men (77 \%), with an estimated 429,793 new cases in 2012 and 165,068 deaths in the same year [7, 8]. Egypt has the highest agestandardized incidence rate (ASR) of bladder cancer in men in NA (21.8/100,000 persons per year), followed by Algeria and Morocco (15.3/100,000 persons per year) and Libya and Tunisia (10.8/100,000 persons per year) (Fig. 1). Egyptian men also have the highest age standardized mortality rate in the world (11.1 per 100,000 men), which is twice the rate in Europe $(5.2 / 100,000)$ and three times that in the United States $(4.0 / 100,000)$ [7]. Consistent with the worldwide data, cases in men comprise a higher fraction of bladder cancer as compared to women in NA (Fig. 1). This observation is likely due to the high prevalence of urinary schistosomiasis, and the high rate of smoking among men [9].

In the 1920s S. haematobium infection rates in Egypt were as high as 70-80\%. As a direct result of several control strategies that have been implemented throughout the country for the last two decades, Egypt has recently reached low schistosomiasis endemicity [10]. The prevalence of schistosomiasis dropped to $6.6 \%$ in 1993 and then to $1.9 \%$ in 2002 and $1.2 \%$ in 2006 [11, 12]. Schistosomiasis is mostly eliminated in both Tunisia and Morocco, as no new cases were reported in these countries since 1984 and 2004, respectively [13]. The Moroccan schistosomiasis elimination strategy started in 1994 and disease transmission was curtailed by 2009 based on

Table 1 Total cancer incidence per 100,000 of most common infection-associated cancers in North African countries ${ }^{\mathrm{a}}$ : Globocan, 2012 [7]

\begin{tabular}{lccccc}
\hline & Morocco & Algeria & Tunisia & Libya & Egypt \\
\hline Bladder (Schistosoma haematobium) & 5.8 & 5.9 & 8.3 & 8.6 & 13.1 \\
Cervix uteri (HPV) & 14.3 & 8.5 & 4.8 & 1.1 & 2.7 \\
Liver (HCV and HBV) & 1.2 & 1.5 & 4.3 & 4.8 & 3.7 \\
Stomach (Helicobacter pylori) & 4.0 & 6.0 & 2.3 & 2.5 \\
Nasopharyngeal (EBV) & 2.3 & 3.2 & 231 & 0.3 \\
\hline
\end{tabular}

${ }^{\mathrm{a}}$ Total cancer incidence (not only the incidence attributed to infectious agents) 


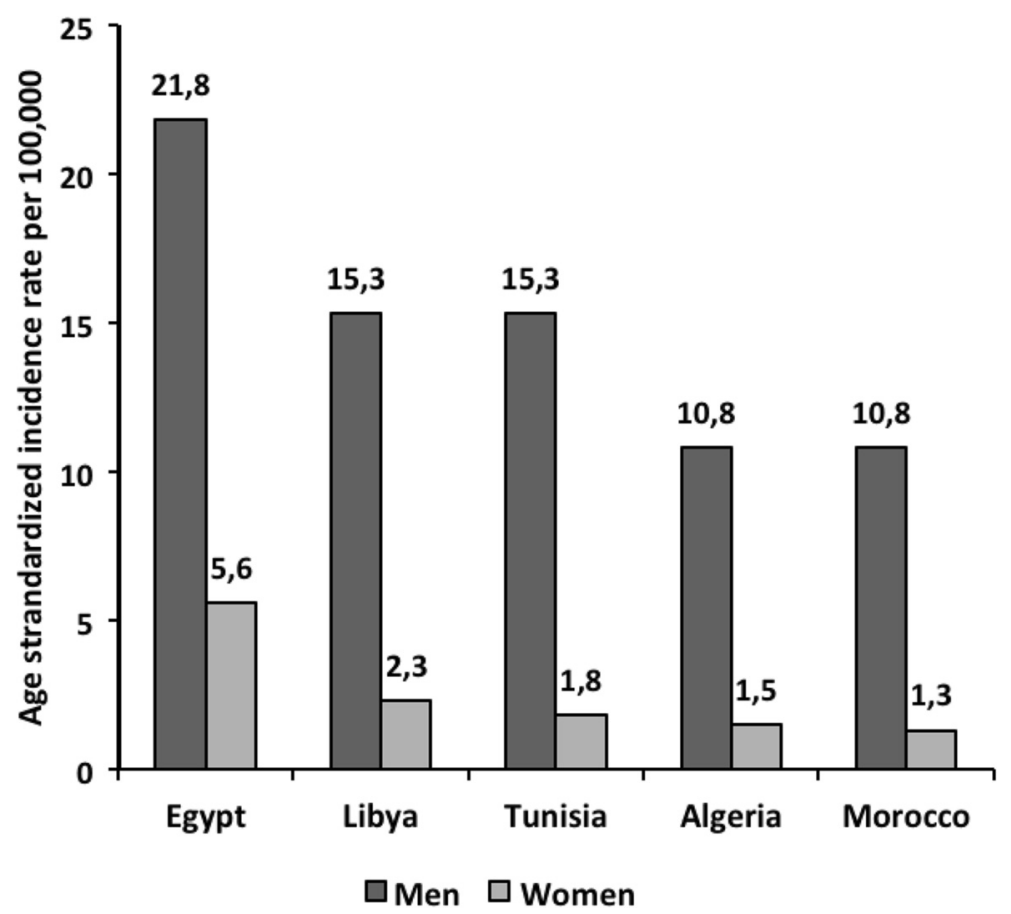

Fig. 1 Estimated age standardized incidence for bladder cancer in North African Countries: Globocan, 2012 [7]. Estimated age standardized incidence for bladder cancer in five North African Countries according to GLOBOCAN 2012 report shows that Egypt has the highest burden of bladder cancer

the absence of serum antibodies, indicating undetectable or complete absence of transmission, in a sample of 2,382 children selected from provinces with a history of high incidence [14]. In Libya, S. haematobium is endemic in some limited regions (near the Mediterranean coast, in the central part and near the southwestern border of Algeria). The estimated prevalence of Schistosoma in Libya between 2003 and 2010 was $5 \%$. In Algeria, S. haematobium is absent in most parts of the country and the risk of infection is localized in the province of Boumerdes [15].

Regarding bladder cancer incidence, the Algerian cancer registry, Setif, reported an increased trend in bladder cancer during a study period of 25 years (from 1986 to 2010). Bladder cancer rates (per 100,000) increased in men from 1.6 in 1986-1990 to 10.3 in 2006-2010 [16]. Similarly, in Morocco, based on the Casablanca cancer population registry, the ASR of bladder cancer increased in men from 5.8 in 2004 to 10.2 in 2007 [17]. Different trends were observed in the other NA countries, with either a stabilized or a decreasing tendency. The incidence rates remained stable over time in Tunisia (1993-2006) [18]. Bladder cancer ASR decreased from 11.7 in 2003 to 3.2 in 2012 among men in Libya [19]. In Egypt, the relative frequency of bladder cancer dropped from $27.6 \%$ in 1970 to $11.7 \%$ in 2007 , which correlates well with a decrease of Schistosoma association from $82.4 \%$ to $55.3 \%$ during the same study period. A significant rise of tobacco-associated transitional cell carcinoma (TCC) from $16 \%$ to $65.8 \%$ and a decrease in SCC from $75.9 \%$ to $28.4 \%$ was however reported for the same period [20].

Shistosomiasis-associated bladder cancer presents a distinctive clinicopathologic profile, different from that reported from the Western countries. In contrast to the Western countries, which predominantly exhibit TCC as the major form of bladder cancer (estimated at 90$95 \%)$, Egypt has reported as much as $75 \%$ of their cases as SCC in the past $[9,21,22]$. Between 1970 and 1974, $26.7 \%$ of patients registered in the National Cancer Institute (NCI) at Cairo University suffered from bladder cancer attributed to schistosomiasis [21]. Another study of 2778 patients at the NCI, showed that bladder cancer patients in 2005 had a six fold increased risk of TCC vs. SCC compared with patients treated in 1980 [23]. Thus, despite the considerable elimination of S. haematobiumrelated infections and hence the resulting bladder cancer, the effect of that had been impeded by tobacco-related bladder cancer among Egyptian men.

\section{Human Papilloma virus and cervical cancer}

Cervical cancer is the world's third most common cancer among women, with an ASR of 14 per 100,000 women. The main bulk of CC cases occur in developing countries (85\%), yet NA countries show an overall low 
incidence (ASR: 6.6 per 100,000). Despite the relatively low incidence rates, $\mathrm{CC}$ is the second most common cancer among women in Algeria and Morocco and the third most common cancer in Tunisia. An increasing East-West gradient exists, ranging from as low as 2.3/ 100,000 women in Egypt to as high as 14.3/100,000 women in Morocco (Fig. 2) [7].

The age specific rates in Algeria and Morocco, were found to increase rapidly with age until $50-54$ or $55-59$ years, and then remained constant (Algeria) or decline (Morocco). Incidence rates reached relatively high values (almost 60/100,000) in Morocco between the ages of 50-54 years and around 40/100,000 in Algeria for ages above 55 years. In Egypt, the incidence rate was lower than 10/100,000 across all age groups. No cases of CC were observed among women below 30 years of age in Algeria, Morocco, and Egypt [24].

Almost $100 \%$ of all CC cases are caused by the HPV, which ranks as the most common sexually transmitted infection globally [3]. There are more than 150 strains of HPV with varying carcinogenic potential. HPV-16 and 18 overshadow other strains $(31,33,35,45,52$ and 58) contributing to over $70 \%$ of all CC cases and being responsible for $41-67 \%$ of high-grade cervical lesions and 16-32\% of low-grade cervical lesions [25-27]. Paucity of published data in the NA region obscure the true epidemiological picture, however it is estimated that HPV prevalence falls between 5-12\% in low-risk population groups and $20-49 \%$ in high-risk groups, with an average of $21.3 \%$ [28]. Data of a meta-analysis also reported that the crude and adjusted HPV prevalence among women with normal cytological findings in NA (Egypt, Tunisia, Morocco and Algeria) were estimated at $10.9 \%$ and $9.2 \%$, respectively [29]. The average prevalence is slightly higher in cases of cervical intraepithelial neoplasia (CIN) and established CC cases (25-90\% and 61$98 \%$, respectively) [28]. Mirroring the global situation, HPV16 is the most prevalent type among diagnosed cancer cases in NA countries (59\%), followed by HPV-18 (8.6-17\%) [30]. According to data available till 2013, NA countries resemble each other in HPV prevalence, which hovers around $10.5 \%$, aside from Tunisia which has a higher national prevalence (14.6\%), reasons for which are presently unclear (Table 2) [31].

\section{Human Papilloma virus and other ano-genital cancers}

While HPV is the major cause of various types of anogenital cancers, such as anal, vulvar, vaginal, and penile cancers, few studies report this correlation perhaps due to their low incidence rates, and a focus on $\mathrm{CC}$, respectively. Anal cancer has a low worldwide incidence of 1 per 100,000 in the general population. Interestingly, the majority of vulvar cases were found in developed nations. Contrary to vulvar cancer, a higher prevalence

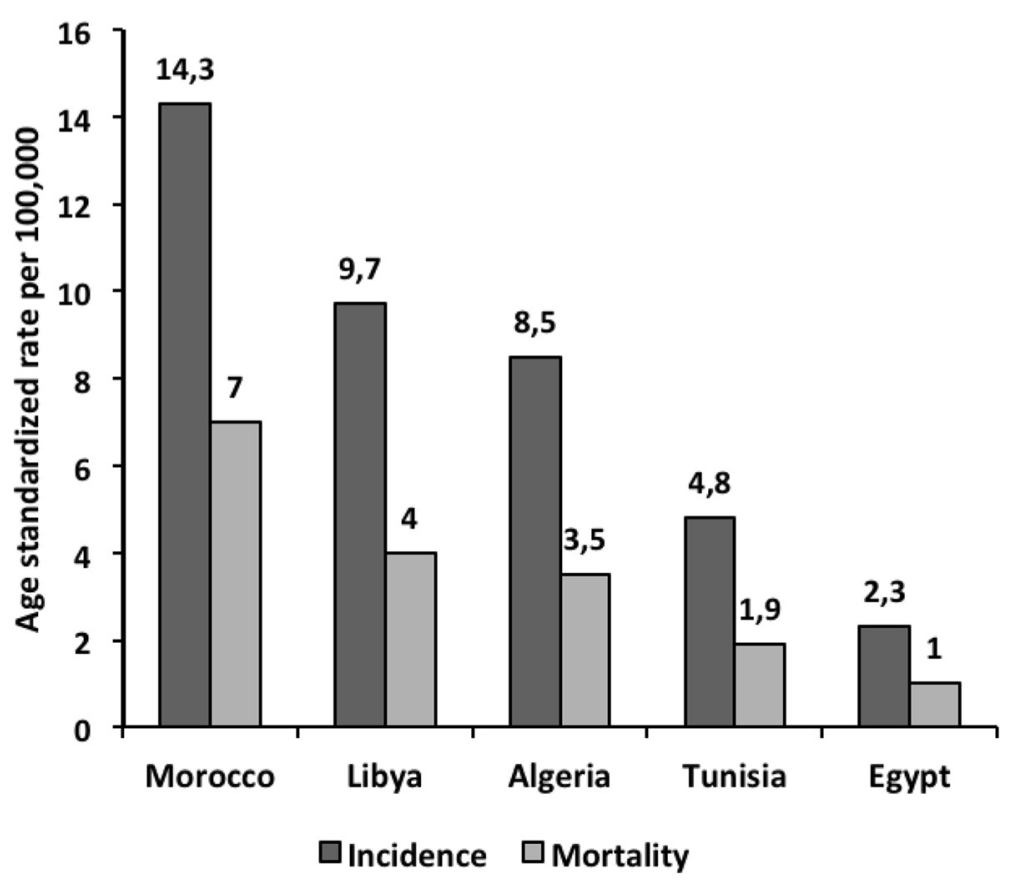

Fig. 2 Estimated age standardized incidence and mortality rates for cervical cancer in North African countries: Globocan, 2012 [7]. Estimated age standardized incidence and mortality rates for cervical cancer in five North African countries according to GLOBOCAN 2012 report shows an increasing East-West gradient of cervical cancer 
Table 2 HPV prevalence in North African countries among different cell types according to data available till 2013 [31]

\begin{tabular}{llllll}
\hline Country & HPV prevalence in women & \multicolumn{2}{l}{ HPV 16 and/or 18 in women with } & & \\
\cline { 3 - 6 } & with normal cytology & Normal cytology & Low grade lesions & High grade lesions & Cervical cancer \\
\hline Egypt & 10.5 & 5.1 & 18.5 & 40 & 78.4 \\
Libya & 10.7 & 5.1 & 18.5 & 40 & 78.4 \\
Tunisia & 14.6 & 5.2 & 18.5 & 40 & 78.4 \\
Algeria & 10.5 & 9 & 18.5 & 40 & 77.1 \\
Morocco & 10.5 & 2.9 & 20.9 & 40 & 79.2 \\
\hline
\end{tabular}

(68 \%) of vaginal cancer was observed in developing nations. Equally rare is worldwide incidence of penile cancer (22,000 new cases/year), which is highly positively correlated with CC [32-34]. Low incidences of anogenital cancers have been reported across NA countries. ASRs of ano-genital cancers in NA countries did not exceed 3.1/100,000 for anal cancers, 0.7 for vulvar cancer and 0.4 for vaginal cancer (Table 3). Libya and Morocco do not currently have any official, published data [35-37].

The only available data on HPV in anogenital cancers from NA are from a population from west Algeria, reporting a prevalence of HPV of $40 \%$ in vaginal cancers, $17 \%$ in vulvar cancers and $33 \%$ in anal cancers [38].

\section{Viral hepatitis and liver cancer}

Globally, liver cancer or HCC is the fifth cancer among men ( $7.5 \%$ of all cancers in men) and the ninth among women (3.4\% of all cancers in women). About $85 \%$ of cases occur in developing countries with 2.4:1 male to female ratio [7, 39]. In NA, liver cancer is the most common cancer in men and the second most common one among women with an estimated ASR of 18 and 7 per 100,000 men and women, respectively. A large disparity exists with a decreasing East-West gradient observed across the region, where incidence in both sexes ranges from a lowest of 1.1/100,000 in Tunisia to a highest of 25.5/100,000 in Egypt (Fig. 3). In Egypt, the male:female ratio reaches $3.8: 1$, probably due to the higher prevalence

Table 3 Age-standardized incidence rate (ASR) of ano-genital cancers in North African countries [35-37]

\begin{tabular}{|c|c|c|c|}
\hline & Egypt & Tunisia & Algeria \\
\hline Anal cancer & 0.4 & 0.2 & $\begin{array}{l}\text { Algiers: } \\
\text { Male } 3.1 \text {; Female } 2.5 \\
\text { Setif region: } \\
\text { Male } 0.1 \text {; Female } 0.1\end{array}$ \\
\hline Vulvar cancer & 0.7 & 0.3 & $\begin{array}{l}\text { Algiers: } 0.1 \\
\text { Setif region: } 0.0\end{array}$ \\
\hline Vaginal cancer & 0.2 & 0.4 & $\begin{array}{l}\text { Algiers: } 0.1 \\
\text { Setif region:0.2 }\end{array}$ \\
\hline Penile cancer & 0.0 & 0.0 & $\begin{array}{l}\text { Algiers : } 0.0 \\
\text { Setif region:0.0 }\end{array}$ \\
\hline
\end{tabular}

of HBV and HCV among men. In addition, the relatively high rates of NHL in Egypt may be explained, in part, by the high HCV prevalence in the country [7].

About $5 \%$ of all cancers are thought to be the direct result of chronic infections with hepatitis viruses [3]. A strong geographic correlation has been found globally between the incidence of liver cancer and the prevalence of hepatitis B surface antigen ( $\mathrm{HBsAg}$ ) or hepatitis C antibody (anti-HCV) [40-43]. Chronic HCV is implicated in most HCC cases in developed countries and in one-third of cases in developing countries [44]. In NA there is a 33-fold increase in HCC with HCV infection and a 10-fold increase with HBV infection [45]. In addition, there is evidence for a causative association between chronic HCV infection and non-Hodgkin lymphoma (NHL), although the underlying mechanism is still not fully understood [46-48].

\section{Hepatitis B}

Most NA countries have an intermediate endemicity of HBV (Table 4) [49]. In Algeria, there is a significant lack of recent data on the prevalence of $\mathrm{HbsAg}$ in the general population, with the last publication dating back almost 20 years ago. The WHO estimates the prevalence in Algeria to stand anywhere between $2 \%$ to $7 \%$, while Khelifa et al. reported it as $2.2 \%$ in North Eastern regions in 1998 with HBV genotype D being the most common there accounting for $93 \%$ of all HBV infections [50].

The sero-prevalence of HBsAg in the general population in Libya varies between $1.3 \%$ and $5.8 \%$. A national seroepidemiological study conducted between 2004 and 2005 showed a prevalence of $2.2 \%$ with 120,000-150,000 chronic HBsAg carriers [51]. A study on hemodialysis patients detected HBsAg prevalence of $2.6 \%$ [52]. A low prevalence $(1.3 \%)$ was found among blood donors. HBV genotype D is the most prevalent in Libya [53].

Morocco has a low estimated prevalence for chronic $\mathrm{HBV}$, ranging between $1 \%$ and $3 \%$ [54-58]. The HBsAg burden in the general population is $1.5 \%$, which was similar to that reported among health professionals (1\%), yet this figure increases to $1.7 \%$ among sexually active subjects and to $2 \%$ among hemodialysis patients [54-56, 59]. At Moroccan blood banks, the prevalence 


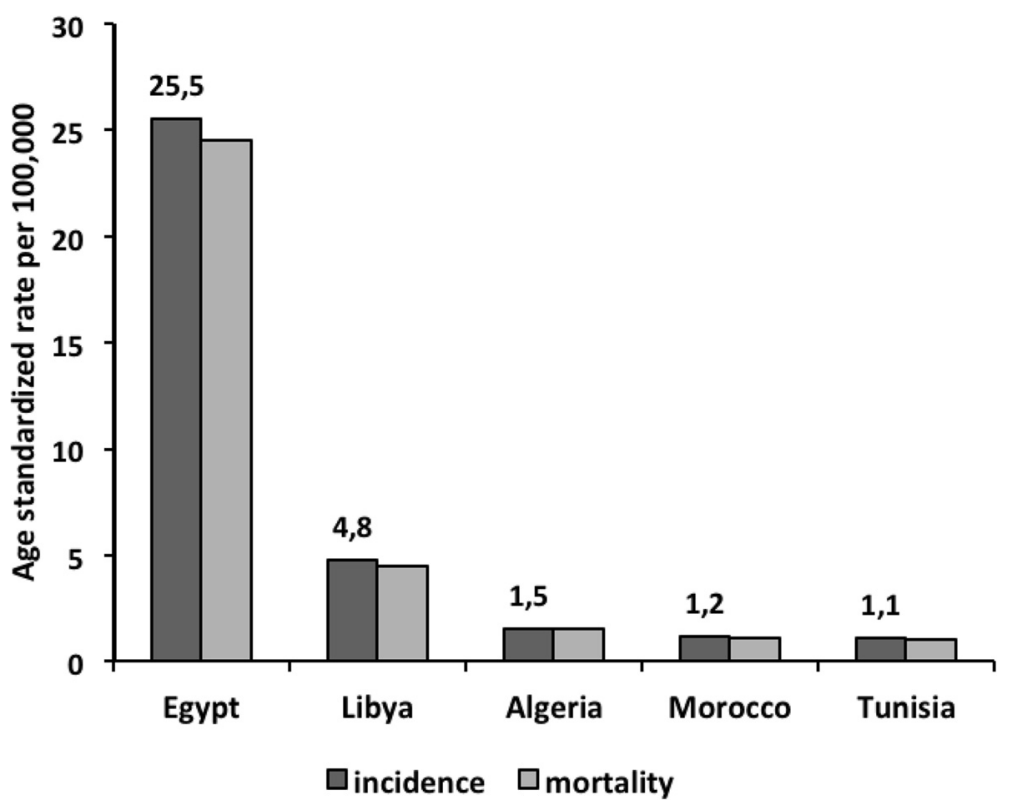

Fig. 3 Estimated age standardized incidence and mortality rates for liver cancer (in both sexes) in North African countries: Globocan, 2012. [7]. Estimated age standardized incidence and mortality rates for liver cancer in five North African countries according to GLOBOCAN 2012 report shows that Egypt has the highest burden of liver cancer with a decreasing East-West gradient

has remarkably decreased between 2000 and 2010 from $2.5-2.8 \%$ to $0.8-1.3 \%[57,59,60]$. HBV genotype D accounts for $90 \%$ of all HBV infections in Morocco [61].

In Tunisia, the estimated HBV prevalence ranges between $2 \%$ and $7 \%$, being highest in South and Midwest regions. A survey on blood donors in 1994 revealed a prevalence of $5 \%$ [62]. In 2010, the overall prevalence of HBsAg burden in a population of chronic carriers and of volunteers was $5.3 \%$ and $2.9 \%$ respectively. A large study conducted in 1997 found that $6.5 \%$ of the study group was HBsAg positive [63]. HBV genotype D was found in $80 \%$ of patients in Tunisia with dominant subgenotype D7 [64, 65].

In Egypt, an earlier study reported $\mathrm{HBsAg}$ prevalence between $8 \%$ and $11.7 \%$ [66]. Recently, HBV prevalence in the general population has been varying from $1.3 \%$ to $6.7 \%$ [49]. Recent blood donor screening revealed a prevalence of HBsAg of 1.3-1.4 \% [67, 68]. However, another cross-sectional study found that $16.6 \%$ of blood donors were positive for total anti-HBV core antibodies of which $64 \%$ were positive for HBsAg [69]. The prevalence of HBV among Egyptian liver cancer patients was $25.9 \%$ and was shown to decrease over time [70]. HBV genotype D accounts for an estimated $87 \%$ of the total infection in Egypt [71].

\section{Hepatitis C}

The global HCV prevalence is $2.35 \%$ with estimated 160 million chronically-infected people [72]. It is a major cause of severe liver disease resulting in 0.35 million annual deaths [73]. HCV infection is a major public health issue in the NA Maghreb region (Morocco, Mauritania, Algeria, Tunisia, and Libya), where the prevalence ranges between 1-2 \%. The highest prevalence however is reported in Egypt, ranging from $6 \%$ to $28 \%$ with an average of $14.7 \%$ [74]. In addition, immigrants from the NA region to Europe were shown to have a higher prevalence compared to the general European Union population in

Table 4 Prevalence of HBV in North African countries according to data available till 2013 [49]

\begin{tabular}{lllll}
\hline Country & HBV prevalence (\%) in population & HBV prevalence (\%) in Hemodialysis patients & Most common genotypes & Less common genotypes \\
\hline Egypt & 4 & 4.1 & D & Subtype D1 \\
Libya & $2-7$ & $2.6[52]$ & D & A, E \\
Tunisia & $2-7$ & No data & D & D \\
Algeria & 3.6 & No data & D & A \\
Morocco & 1.3 & 2 & D
\end{tabular}


host countries, raising the issue of national immigrant screening programs [75-77].

In Algeria, a survey conducted in 1995 among blood donors and pregnant women, found an HCV prevalence of $0.2 \%$ [78]. The Algerian Ministry of Health estimated that the prevalence had reached $2.5 \%$ in 2009 [79]. High prevalence rates, were found among hemodialysis patients ( $25 \%$ to $53 \%)$ and in hemophiliacs (31.6\%) [80]. In Algeria, subtype $1 \mathrm{~b}$ is the most prevalent genotype (86.2 \%) [81].

In the mid-1990s, the prevalence of HCV cases among Libyan general population was $8 \%$ and was labeled as 'community acquired' [82]. A more recent national seroepidemiological survey denoted that the prevalence had declined to $1.2 \%$ [51]. Prevalence was higher among renal dialysis (20.5 \%) and poly-transfused patients (11 \%), transmission being mainly nosocomial [83]. Genotype 4 was the most common (35.7\%), followed by genotype 1 (32.6 \%) [84].

In Morocco, the estimated prevalence among the general population and blood donors was $0.3 \%$ and $2 \%$ respectively [85-87]. The highest prevalence rates were observed in hemodialysis patients (34\%-68\%), hemophiliac patients (42\%), and intravenous drug users (60.1\%) [85, 88-91]. A survey conducted in 2001 in Casablanca revealed a $5 \%$ prevalence of anti-HCV antibodies in traditional barbers. A more recent study showed a low prevalence among young army recruits $(0.35 \%)$, blood donors $(0.33 \%)$, and hospitalized patients (3.08\%) [60]. The most commonly found HCV genotypes were $1 \mathrm{~b}(47.6 \%), 2 \mathrm{a} / 2 \mathrm{c}(37.1 \%)$ and $1 \mathrm{a}(2.8 \%)$ respectively [92].

In Tunisia, the average prevalence of anti-HCV antibodies is $1.6 \%$ ranging between $0.3 \%$ in the south and $3 \%$ in the northwest region where several reports revealed the presence of a chronic hepatitis $C$ cluster. An average prevalence of $0.6 \%$ was reported in blood donors. Genotype $1 \mathrm{~b}$ predominates and the prevalence ranges from $79 \%$ to $90 \%$ [62, 93-95].

The Egyptian Demographic Health Survey of 2008 estimated the prevalence of anti-HCV antibodies to be $14.7 \%$; the highest in the world to date. This inflated prevalence is thought to be associated with the mass parenteral anti-schistosomiasis therapy implemented during the 1950s-1980s [96-98] resulting in a large reservoir of chronic HCV. Between 2000 and 2007 the annual seroprevalence of $\mathrm{HCV}$ among blood donors declined from $17.7 \%$ to $7.4 \%$ [67]. However, ongoing endemic transmission is suggested with an estimated incidence of nearly $6.9 / 1,000$ persons per year $[96,99]$. HCV genotype G4 is the most common genotype in Egypt [98].

A meta-analysis of 32 case-control studies reported that co-infection with HBV and HCV is strongly associated with $\mathrm{HCC}(\mathrm{OR}=165)$, compared with monoinfection with $\mathrm{HCV}(\mathrm{OR}=17)$ or $\mathrm{HBV}(\mathrm{OR}=23)$ [100].
Similarly, a recent study in the NA region reported a 33fold increase in HCC with HCV infection and a 10-fold increase with HBV infection [ 45]. This risk increased 84-fold when patients were co-infected by both viruses, suggesting a synergistic effect between the two infections, although the exact mechanism has not yet been established.

A multicenter case-control study conducted between 2002 and 2005 in patients with HCC from Algeria, Morocco and Tunisia, reported that $60 \%$ of HCC patients were positive for anti-HCV and $18 \%$ for HBsAg [45]. In Egypt, there was a significant increase in the annual proportion of patients with $\mathrm{HCC}$ among chronic liver disease patients attending the Cairo liver center, during a study period ranging from $4.0 \%$ in 1993 to $7.2 \%$ in 2002, with a significant drop of HBsAg positivity among HCC patients from $38.6 \%$ to $20.5 \%$ and a slight increase of $\mathrm{HCV}$ positivity from $85.6 \%$ to $87.9 \%$ [101].

The Algerian Cancer Registry in Setif was the only one that could provide longitudinal data on HCC over a 25year period (from 1986 to 2010). The liver cancer rate was found to increase since 1996-2000 after a decrease for both sexes (annual percent changes of $+8.9 \%$ in men and $+5.4 \%$ in women) [16]. In Libya, no significant change in liver cancer incidence was observed between $2003(\mathrm{ASR}=3.3)$ and $2012(\mathrm{ASR}=4))$ [19].

\section{H. Pylori and stomach cancer}

Stomach cancer is the 4th common cancer in men and the 6th in women worldwide with an ASR of 17.4 and 7.5 per 100,000 respectively. Stomach cancer incidence is much less in NA (ASR: 4.3 and 2.7 per 100,000 in men and women, respectively) with an increasing EastWest gradient (Fig. 4) [7].

$H$. pylori infection is the etiological agent in various gastric pathologies and the disease severity has been attributed to some $H$. pylori genotypes [102]. It is estimated that $H$. pylori infection increases the risk of stomach cancer by nearly six times. Prevalence rates differ by age, ethnicity and socioeconomic characteristics, being higher in developing countries [103].

In Morocco, a $69 \%$ prevalence of $H$. pylori infection was found among patients with digestive complaints. Commonly infected sites were the atrium (73\%), the corpus $(21 \%)$ and the pylorus (6\%). The potentially carcinogenic cagA antigen was detected in $42.3 \%$ of cases [104]. In Egypt, several studies showed high prevalence of infection in various settings. $H$. pylori IgG antibodies were detected in $68 \%$ of a group of women with primary fibromyalgia [105]. H. pylori prevalence of $72.38 \%$ was found among school children [106]. In Tunisia, $66.7 \%$ of a group of symptomatic patients were seropositive for $H$. pylori compared to $64 \%$ of a group of blood-donors [107]. The prevalence of $H$. pylori infection reached 


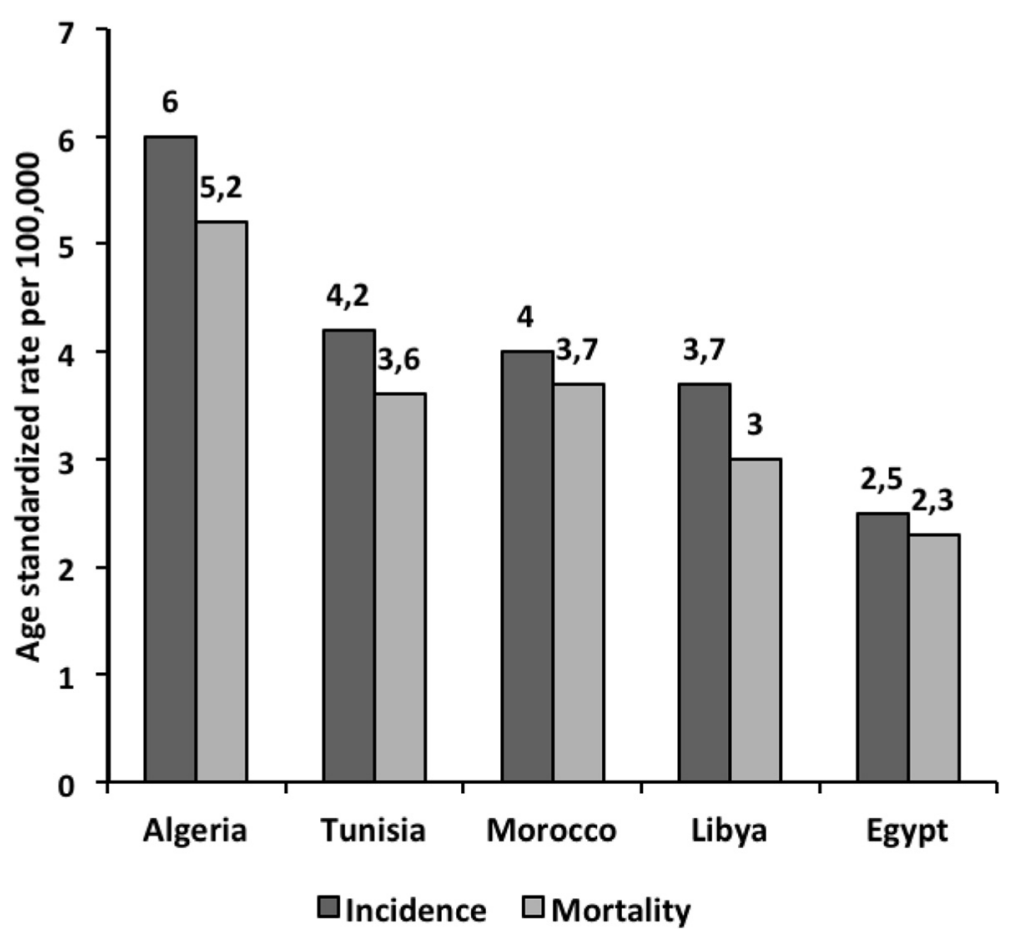

Fig. 4 Estimated age standardized incidence and mortality rates for stomach cancer (in both sexes) in North African countries: Globocan, 2012 [7]. Estimated age standardized incidence and mortality rates for stomach cancer in five North African countries according to GLOBOCAN 2012 report shows that Algeria has the highest burden of stomach cancer

$51.4 \%$ among six-year old children [108]. The estimated prevalence of $H$. pylori infection in Algeria was over $70 \%$ [109]. In 1989, a sero-epidemiological study found that the prevalence among children in the first decade of life was $45 \%$ which rose steadily to reach $92 \%$ among those in the fifth decade [110]. Despite the high infection rates in NA countries, stomach cancer remains relatively low, indicating that other determinants such as genetic factors or virulence of the organism influence the carcinogenic potential and ultimate cancer development.

\section{Epstein-Barr virus associated cancers}

NPC is the 22nd most common cancer worldwide, but it is the 6th most common cancer in NA. In addition to NA it is prevalent in Southern China, Southeast Asia, Japan and the Middle East $[111,112]$. EBV is a group I carcinogen, implicated in NPC, Burkitt's Lymphoma, Hodgkin's, non-Hodgkin's and T cell lymphoma [113].

EBV infects over $95 \%$ of the global adult population [114], yet NPC results from an interaction between EBV infection and environmental/genetic factors [112]. The highest observed incidence of NPC in NA is in Algeria $(3.2 / 100,000)$ and the lowest is in Egypt with 0.3/100,000 (Fig. 5). Interestingly, some typical NA foods seem to be associated with increased risk of NPC [115, 116]. A study conducted over 4 years (2002-2005), in Morocco,
Algeria and Tunisia reported that the consumption of butyric acid (found in rancid butter (smen), rancid sheep fat, and dried mutton stored in oil (quaddid)) was significantly associated with an increased risk of NPC, with the presence of butyric acid in these traditional foods acting as a potential EBV activator [116].

\section{HHV8 and Kaposi's sarcoma}

Kaposi's sarcoma (KS) does not appear in the top 25 cancers in the world, however, it is the 10th most common cancer in Africa, with an ASR of 4.7/100,000 probably due to the high prevalence of HIV [7]. In Morocco, antiHHV8 antibody was found in $92 \%$ of KS cases, mostly affecting males $[117,118]$. Kaposi sarcoma was the cause of death in $6 \%$ of a sample of HIV-positive patients [119].

In Tunisia, the sero-prevalence of HHV8 was $13.8 \%$ in blood donors, $13 \%$ in pregnant women, and $12 \%$ in children [120]. HHV8 was found in $17 \%$ of kidney transplant patients [121]. Another study noted that $7 \%$ of adult renal transplant recipients developed various cancers, of which $41.6 \%$ developed KS [122]. Kaposi sarcoma was found in $4.5 \%$ of skin cancer patients registered in southern Tunisia over a period of 24 years (1979-2002) [123]. In a small cohort with acquired immunodeficiency syndrome (AIDS), KS emerged in $22.7 \%$ of cases within 0 to 10 years. This time frame was similar in the neighboring Morocco 


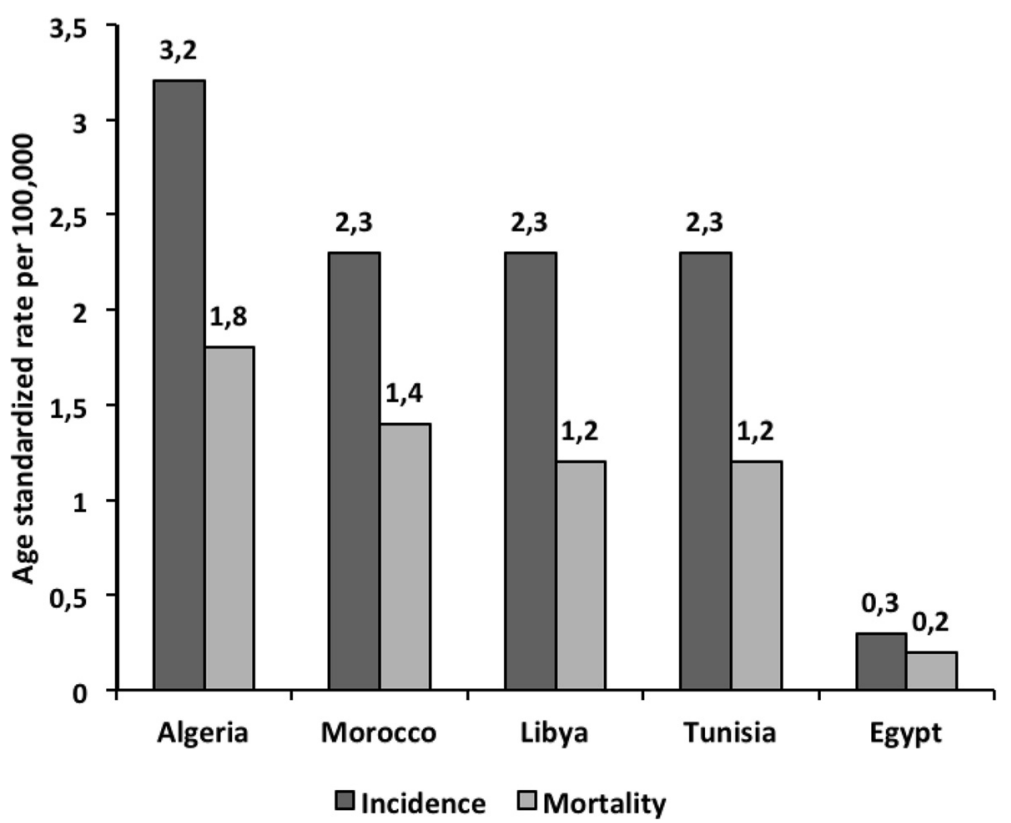

Fig. 5 Estimated age standardized incidence and mortality rates for NPC (in both sexes) in North African Countries: Globocan, 2012 [7]. Estimated age standardized incidence and mortality rates for NPC in five North African countries according to GLOBOCAN 2012 report shows highest levels of NPC in Algeria

[124]. In Egypt, a prospective study on 1-4 year old children with febrile syndrome showed that $41.9 \%$ were seropositive for HHV-8 [125]. There is a general lack of data on this subject in Algeria.

\section{HTLV-1 and T-cell Leukemia}

There is a close association between T-cell Leukemia and the presence of antibodies to HTLV-I [126]. However, few studies have been carried out in the last decade in Africa and the number of tested individuals is limited. Sero-positivity for HTLV-I in Morocco is $0.6 \%$. In Tunisia, Algeria and Egypt, HTLV-I/II infections were not observed in blood donors or recipients [127].

\section{Conclusion}

Differences in the rates of infection-related cancers across NA countries are manifested in the high incidence of bladder and liver cancers and NHL in Egypt versus the remarkably increasing East-West gradient of CC. Rates of NPC were also high in all the NA countries except Egypt.

The burden of infection-related cancers is still underestimated worldwide and associations with new infectious agents remain yet to be explored. If infectious diseases associated with cancers were prevented, it is estimated that there would be $26.3 \%$ fewer cancer cases in developing countries and $7.7 \%$ in developed countries.

The administration of the HBV vaccine in addition to the routine screening of blood and blood products for HBV and HVC have resulted in a reduced incidence of liver cancer. Furthermore, HPV vaccines which protect against HPV-16 \& 18 are now available and have the potential to reduce the incidence of $\mathrm{CC}$. A paradox is the incidence of SCC of bladder cancer, which markedly decreased in Egypt as a result of the success of schistosomiasis control, although increased smoking doubtless is a factor contributing to the increased proportion of TCC bladder cancer in Egypt. The intermediate prevalence of many communicable diseases in NA requires a constant epidemiological surveillance and the rapid adoption of available preventative vaccines in addition to health education about region-specific risk factors. Therefore the strategy should shift from a therapy-based one which is employed after the development of a specific malignancy is linked to an infectious agent to a preventative one based on national vaccination campaigns, population education on risk factors and other lifestyle-related preventative measures.

\section{Abbreviations}

AIDS, Acquired immunodeficiency syndrome; ASR, Age standardized incidence rate; CC, Cervical cancer; EBV, Epstein-Barr virus; H. pylori, Helicobacter pylori; HBsAg, Hepatitis B surface antigen; HBV, Hepatitis B Virus; HCC, Hepatocellular carcinoma; HCV, Hepatitis C Virus; HHV-8, Human herpes virus type 8; HIV-1, Human immunodeficiency virus; HPV, Human papillomavirus; HTLV-1, Human T-cell lymphotropic virus type 1; IARC, International Agency for Research on Cancer; IgG, Immunoglobulin G; KS, Kaposi's sarcoma; KSHV, Kaposi sarcoma- associated herpes virus; NA countries, North African countries (Egypt, Libya, Tunisia, Algeria and Morocco); NA, North Africa; NCl, National Cancer Institute at Cairo University; NHL, Non-Hodgkin lymphoma; NPC, Nasopharyngeal carcinoma; OR, Odds ratio; S. haematobium, Schistisoma haematobium; SCC, Squamous cell carcinoma; TCC, Transitional cell carcinoma; WHO, World Health Organization 


\section{Acknowledgement}

This study was financially supported by the European Union, EU FP7/20072013 grant 260715. The funders had no role in study design, decision to publish, or preparation of the manuscript.

\section{Authors' contributions}

WAA, MK, MA and AF planned the study. WAA, WMH, LM and MK performed the literature search. WAA, MK, LM and MA evaluated research articles included. WMH and RDT wrote review sections, figures and tables. WAA, LM, $A F, M K$, and RDT revised and edited to obtain the final format. All authors read and approved the final manuscript.

\section{Authors' information}

WMH is a research assistant with a Master's degree in public health and M.B.B.Ch degree in Medicine.

WAA is a professor of public health with a broad experience in epidemiology and mutagenesis research.

MA is a researcher with a broad experience in cancers associated with viruses.

LM is a researcher with background in stem cell research and oncogenesis. $\mathrm{AF}$ is a scientist with a great experience in research on cancer epidemiology and cancer risk factors and prevention.

RDT holds a BSc in Molecular Biology and an MSc in Biotechnology; her work focuses on virology and epidemiological research.

MK is a researcher with a great experience in infectious diseases and cancer research.

\section{Competing interests}

The authors declare that they have no competing interests.

\section{Author details}

${ }^{1}$ Department of Community, Environmental and Occupational Medicine, Faculty of Medicine, Ain ShamsUniversity, Cairo, Egypt. ${ }^{2}$ Biology and Medical Research Unit, National Center of Energy, Sciences and Nuclear Technics, Rabat, Morocco. ${ }^{3}$ Laboratory of Onco-virology, Institut Pasteur du Maroc, Casablanca, Morocco. ${ }^{4}$ Department of Molecular Genetic Epidemiology, German Cancer Research Center (DKFZ), Heidelberg, Germany. ${ }^{5}$ Center for Primary Health Care Research, Clinical Research Center, Lund University, Malmö, Sweden.

Received: 31 March 2016 Accepted: 9 June 2016

\section{Published online: 10 August 2016}

\section{References}

1. de Martel C, Farley J, Franceschi S, Bray F, Forman D, Plummer M. Global burden of cancers attributable to infections in 2008: a review and synthetic analysis. Lancet Oncol. 2012;13(6):607-15.

2. Jemal A, Center MM, DeSantis C, Ward EM. Global patterns of cancer incidence and mortality rates and trends. Cancer Epidemiol Biomarkers Prev. 2010;19(8):1893-907.

3. Parkin DM. The global health burden of infection-associated cancers in the year 2002. Int J Cancer. 2006;118(12):3030-44.

4. World Health Organization, International Agency for Rresearch on Cancer, IARC Monographs on the Evaluation of Carcinogenic Risks to Humans: Biological agents, 2012; 100 B: 39-40. [http://publications.iarc.fr/Book-AndReport-Series/larc-Monographs-On-The-Evaluation-Of-Carcinogenic-Risks-ToHumans/Biological-Agents-2012]. Accessed 1 Mar 2016.

5. Zanetti R, Tazi MA, Rosso S. New data tells us more about cancer incidence in North Africa. Eur J Cancer. 2010;46(3):462-6.

6. Bray F, Ren JS, Masuyer E, Ferlay J. Global estimates of cancer prevalence for 27 sites in the adult population in 2008. Int J Cancer. 2013;132(5):1133-45.

7. Ferlay J, Soerjomataram I, Ervik M, Dikshit R, Eser S, Mathers C, Rebelo M, Parkin DM, Forman D, Bray F. GLOBOCAN 2012 v1.0, Cancer Incidence and Mortality Worldwide: IARC Cancer Base No. 11 [Internet]. Lyon, France: International Agency for Research on Cancer; 2010 [http://globocan.iarc.fr, Accessed on 25/12/2013., 2013].

8. Parkin D. The global burden of urinary bladder cancer. Scand J Urol Nephrol. 2008:42 Suppl 218:12-20.

9. Khaled H. Schistosomiasis and Cancer in Egypt: Review. J Adv Res. 2013;4(5):461-6.
10. Steinmann P, Keiser J, Bos R, Tanner M, Utzinger J. Schistosomiasis and water resources development: Systematic review, meta-analysis, and estimates of people at risk. Lancet Infect Dis. 2006;6(7):411-25.

11. El Khoby T, Galal N, Fenwick A. The USAID/Government Egypt's Schistosomiasis Research Project (SRP). Parasitol Today. 1998;14:92-6.

12. World Bank. Egypt-National Schistosomiasis Control Project. Washington, DC: World Bank; 2008. [http://documents.worldbank.org/curated/en/2008/06/ 9689864/egypt-national-schistosomiasis-controlproject]. Accessed 1 Mar 2016.

13. WHO. Schistosomiasis number of people treated 2009. Wkly Epidemiol Rec. 2011;86:73-80.

14. Amarir F, El Mansouri B, Fellah H, Sebti F, Mohammed L, Handali S, et al National serologic survey of Haematobium schistosomiasis in Morocco evidence for elimination. Am J Trop Med Hyg. 2011;84(1):15-9.

15. 15. Barakat R, El Morshedy H, Farghaly A. Human Schistosomiasis in the Middle East and North Africa Region. In: Neglected tropical diseases Middle East and North Africa. Mary Ann McDowell, Sima Rafati: SpringerVerlag Wien; 2014. [http://link.springer.com/book/10.1007/978-3-7091-16135]. Accessed 1 Mar 2016

16. Hamdi Cherif M, Serraino D, Mahnane A, Laouamri S, Zaidi Z, Boukharouba $\mathrm{H}$, et al. Time trends of cancer incidence in Setif, Algeria, 1986-2010. BMC Cancer. 2014;14:637.

17. Obtel M, Lyoussi B, Tachfouti N, Mathoulin Pelissier N, Nejjari C. Using surveillance data to understand cancer trends: an overview in Morocco. Archives of Public Health. 2015;73:45-51.

18. Missaoui N, Trabelsi A, Parkin DM, Jaidene L, Chatti D, Mokni M, et al. Trends in the incidence of cancer in the Sousse region, Tunisia, 1993-2006. Int J Cancer. 2010;127:2669-77.

19. Bodalal Z, Azzuz R, Bendardaf R. Cancers in Eastern Libya: First results from Benghazi Medical Center. World J Gastroenterol. 2014;20:6293-301.

20. Gouda I, Mokhtar N, Bilal D, El-Bolkainy T, El-Bolkainy MN. Bilharziasis and bladder cancer: a time trend analysis of 9843 patients. J Egypt Nat Cancer Inst. 2007:19(2):158-62.

21. El Sebaie I, El Bolkainy M, Hussein M. Cancer Institute registry. Med J Cairo Univ. 1973:41:175-82

22. Lamm DL, Tori FM. Bladder Cancer. Cancer J Clin. 1996;46:93-113.

23. Felix AS, Soliman AS, Khaled $H$, Zaghloul MS, Banerjee M, El-Baradie M, et al. The changing pattern of bladder cancer in Egypt over the past 26 years. Cancer Causes Control. 2008;19(4):421-9.

24. Vaccarella S, Bruni L, Seoud M. Burden of human papilloma virus infections and related diseases in the extended Middle East and North Africa region. Vaccine. 2013;315:G32-44.

25. Walboomers JM, Jacobs MV, Manos MM, Bosch FX, Kummer JA, Shah KV, et al. Human papillomavirus is a necessary cause of invasive cervical cancer worldwide. J Pathol. 1999:189(1):12-9.

26. Clifford G, Franceschi S, Diaz M, Muñoz N, Villa LL. Chapter 3: HPV typedistribution in women with and without cervical neoplastic diseases. Vaccine. 2006:31(24):26-34

27. Bosch FX, Lorincz A, Muñoz N, Meijer CJ, Shah KV. The causal relation between human papillomavirus and cervical cancer. J Clin Pathol. 2002:55(4):244-65.

28. Seoud MA, Seoud KM, Lindely S, Anis S. Human papillomavirus (HPV): Burden of the disease in cervical cancer in the extended Middle East and North Africa. A comprehensive review. J Clin Oncol 2009; 27 (suppl; abstr e16577) meeting report (2009 Asco Annual meeting).

29. Bruni L, Diaz M, Catellsague X, Ferrer E, Bosch X, de Sanjose S. Cervical Human Papillomavirus Prevalence in 5 Continents: Meta-Analysis of 1 Million Women with Normal Cytological Findings. J Infect Dis. 2010;202(12):1789-99.

30. Castellsagué X, de Sanjosé S, Aguado T, Louie K.S, Bruni L, Muñoz J, Diaz M, Irwin K, Gacic M, Beauvais O, Albero G, Ferrer E, Byrne S, Bosch F X. HPV and Cervical Cancer in the World 2007 Report. WHO/ICO Information Centre on HPV and Cervical Cancer (HPV Information Centre) [http://www.hpvcentre. net/hpvpublications.php]. Accessed 12 Dec 2016.

31. Bruni L, Barrionuevo-Rosas L, Serrano B, Brotons M, Cosano R, Muñoz J, Bosch F, de Sanjosé S, X. C. ICO Information Centre on HPV and Cancer (HPV Information Centre). Summary Report 2013-12-16 [Data Accessed] 2013

32. Palefsky JM. HPV infection in men. Dis Markers. 2007;23(4):261-72.

33. Zur Hausen $\mathrm{H}$. Papillomaviruses and cancer: from basic studies to clinical application. Nat Rev Cancer. 2002:2(5):342-50.

34. Chin-Hong PV, Palefsky JM. Natural history and clinical management of anal human papillomavirus disease in men and women infected with human immunodeficiency virus. Clin Infect Dis. 2002;35(9):1127-34. 
35. Parkin DM, et al., Cancer Incidence in Five Continents. IARC Scientific Publications No. 155, 2002. VIII.

36. Curado MP, et al., Cancer Incidence in Five Continents. IARC Scientific Publications No. 160, 2007. IX

37. UNESCO Institute for Statistics Data Centre [online database]. Montreal, UNESCO Institute for Statistics, 2012. Available at: http://stats.uis.unesco.org [Accessed on Jan 2013].

38. Nahet A, Boublenza L, Hassaine $H$, Masdoua N, Prétet $J$, Belglaiaa $E$, et al. HPV DNA genotyping: A study of anogenital, head and neck and skin cancers in a population from west Algerian. HPV detection in different cancers from an Algerian population. Bull Cancer. 2016;103:455-60.

39. Jemal A, Bray F, Center MM, Ferlay J, Ward E, Forman D. Global cancer statistics. CA Cancer J Clin. 2011;61(2):69-90.

40. Lu SN, Su WW, Yang SS, Chang TT, Cheng KS, Wu JC, et al. Secular trends and geographic variations of hepatitis B virus and hepatitis $C$ virus-associated hepatocellular carcinoma in Taiwan. Int J Cancer. 2006; 119:1946-52.

41. Huang YH, Wu JC, Chau GY, Tsay SH, King KL, Sheng WY, Lui WY, Lee SD. Detection of serum hepatitis B, C, and D viral nucleic acids and its implications in hepatocellular carcinoma patients. J Gastroenterol. 1998;33:512-6.

42. Lee SD, Lee FY, Wu JC, Hwang SJ, Wang SS, Lo KJ. The prevalence of antihepatitis $C$ virus among Chinese patients with hepatocellular carcinoma. Cancer. 1992:69:342-5.

43. Bosch FX, Ribes J, Díaz M, Cléries R. Primary liver cancer: worldwide incidence and trends. Gastroenterology. 2004;127(5 Suppl 1):S5-16.

44. Dhanasekaran R, Limaye A, Cabrera R. Hepatocellular carcinoma: current trends in worldwide epidemiology, risk factors, diagnosis, and therapeutics. Hepat Med. 2012:4:19-37.

45. Bahri O, Ezzikouri S, Alaya-Bouafif NB, Iguer F, Feydi AE, Mestiri H, et al. First multicenter study for risk factors for hepatocellular carcinoma development in North Africa. World J Hepatol. 2011;3(1):24-30.

46. Gisbert JP, García-Buey L, Pajares JM, Moreno-Otero R. Prevalence of hepatitis C virus infection in B-cell non-Hodgkin's lymphoma: systematic review and meta-analysis. Gastroenterology. 2003;125(6):1723-32.

47. Matsuo K, Kusano A, Sugumar A, Nakamura S, Tajima K, Mueller NE. Effect of hepatitis $C$ virus infection on the risk of non-Hodgkin's lymphoma: a metaanalysis of epidemiological studies. Cancer Sci. 2004;95(9):745-52.

48. Dal Maso L, Franceschi S. Hepatitis $C$ virus and risk of lymphoma and other lymphoid neoplasms: a meta-analysis of epidemiologic studies. Cancer Epidemiol Biomarkers Prev. 2006;15(11):2078-85.

49. Gasim IG. Hepatitis B, virus in the Arab world: Where do we stand? Arab J Gastroenterol. 2013;14:35-43.

50. Khelifa F, Thibault V. Characteristics of hepatitis B viral strains in chronic carrier patients from North-East Algeria. Pathol Biol. 2009:57(1):107-13.

51. Elzouki A, Hepatitis B. C and HIV infection in Libya. Libyan J Infect Dis. 2007; 1:132-3.

52. Alashek WA, Mclntyre CW, Taal MW. Hepatitis B and C infection in haemodialysis patients in Libya: prevalence, incidence and risk factors. BMC Infect Dis. 2012;12:265

53. Salem MA, EM Elnifro EM, Alshuwen F. Molecular Analysis of Hepatitis B Virus Isolates in Libya: Predominant Circulation of Hepatitis B Virus Genotype D. J Gastroenterol Hepatol Res. 2012;1(7):119-21.

54. Ezzikouri S, Chemin I, Chafik A, Wakrim L, Nourlil J, Malki AE, et al. Genotype determination in Moroccan hepatitis B chronic carriers. Infect Genet Evol. 2008:8(3):306-12.

55. Djeriri $K$, Laurichesse $H$, Merle $J$, Charof $R$, Abouyoub A, Fontana $L$, et al. Hepatitis B in Moroccan health care workers. Occup Med. 2008;58(6):419-24.

56. Sbai A, Baha W, Ougabrai H, Allalia T, Dersi N, Lazaar F, et al. Hepatitis B prevalence and risk factors in Morocco. Pathol Biol. 2012;60(5):3.

57. Zohoun A, Hadef R, Zahid H, Benkirane M. Seroprevalence of HBV and HCV in blood donors at the Blood Transfusion Center of Mohammed V Military Teaching Hospital in Rabat Morocco. Med Trop. 2011;71(5):513-4.

58. Heikel J, Sekkat S, Bouqdir F, Rich H, Takourt B, Radouani F, et al. The prevalence of sexually transmitted pathogens in patients presenting to a Casablanca STD clinic. Eur J Epidemio. 1999;15(8):711-5.

59. Benjelloun S, Bennani A, Sekkat S, Benslimane A. Les hépatites virales au Maroc. Aspects épidémiologique et moléculaire [Abstract]. Journées scientifiques de medecine. 2002:60-4:60-4.

60. Aqodad N, Lahbabi M, Elyousfi M, Mellouki I, Benajah D, Elabkari M, et al. Prevalence of VHC-Ab and HBsAg among blood donors in Guelmim in the south of Morocco. Hep Intl. 2011;5(1):96.
61. Baha W, Ennajib MM, Lazara F, Melloulc M, El Fahimec E, El Malkia A, et al. HBV genotypes prevalence, precore and basal core mutants in Morocco. Infect Genet Evol. 2012;12(6):1157-62.

62. Jemni S, Ikbel K, Kortas M, Mahjoub J, Ghachem L, Bidet JM, et al. Seropositivity to hepatitis $C$ virus in Tunisian haemodialysis patients. Nouv Rev Fr Hemato. 1994;36(5):349-51.

63. Triki H, Said N, Ben Salah A, Arrouji A, Ben Ahmed F, Bouguerra A, et al. Seroepidemiology of hepatitis B, C and delta viruses in Tunisia. Trans R Soc Trop Med Hyg. 1997;91(1):11-4.

64. Bahri O, Cheikh I, Hajji N, Djebbi A, Maamouri N, Sadraoui A, et al. Hepatitis B genotypes, precore and core promoter mutants circulating in Tunisia. J Med Virol. 2006;78(3):353-7.

65. Meldal BH, Moula NM, Barnes IH, Boukef K, Allain JP. A novel hepatitis B virus subgenotype, D7, in Tunisian blood donors. J Gen Virol. 2009;90(Pt 7): $1622-8$

66. Sherif MM, Abou-Aita BA, Abou-Elew MH, el-Kafrawi AO. Hepatitis B virus infection in upper and lower Egypt. J Med Virol. 1985;15(2):129-35.

67. Ismail AM, Ziada HN, Sheashaa HA, Shehab El-Din AB. Decline of viral hepatitis prevalence among asymptomatic Egyptian blood donors: a glimmer of hope. Eur J Intern Med. 2009;20(5):490-3.

68. Wasfi OA, Sadek NA. Prevalence of hepatitis B surface antigen and hepatitis $C$ virus antibodies among blood donors in Alexandria. Egypt East Mediterr Health J. 2011;17(3):238-42.

69. Said ZN, Sayed MH, Salama II, Aboel-Magd EK, Mahmoud MH, Setouhy ME, et al. Occult hepatitis B virus infection among Egyptian blood donors. World J Hepatol. 2013;5(2):64-73.

70. Lehman EM, Wilson ML. Epidemiology of hepatitis viruses among hepatocellular carcinoma cases and healthy people in Egypt: a systematic review and meta-analysis. Int J Cancer. 2009;124(3):690-7.

71. Khaled IA, Mahmoud OM, Saleh AF, Bioumie EE. Prevalence of HBV genotypes among Egyptian hepatitis patients. Mol Biol Rep. 2011;38(7):4353-7.

72. Lavanchy D. Evolving epidemiology of hepatitis C virus. Clin Microbiol Infect. 2011;17(2):107-15

73. Perz JF, Armstrong GL, Farrington LA, Hutin YJ, Bell BP. The contributions of hepatitis $B$ virus and hepatitis $C$ virus infections to cirrhosis and primary liver cancer worldwide. J Hepatol. 2006:45(4):529-38.

74. Guerra J, Garenne M, Mohamed MK, Fontanet A. HCV burden of infection in Egypt: results from a nationwide survey. J Viral Hepat. 2012 19(8):560-7.

75. Roudot-Thoraval F, Deforges L, Girollet PP, Maria B, Milliez J, Pathier D, Duval J, Dhumeaux D. Prevalence of hepatitis C virus antibodies (tests ELISA 2 and RIBA 2) in a population of pregnant women in France. Gastroenterol Clin Biol. 1992;16(3):255-9. Article in French.

76. Chiaramonte M, Pupo A, Menegon T, Baldo V, Malatesta R, Trivello R. HBV and HCV infection among non-European Union immigrants in North-East Italy. Epidemiol Infect. 1998;121(1):179-83.

77. Hemminki K, Mousavi SM, Brandt A, Ji J, Sundquist J. Liver and gallbladder cancer in immigrants to Sweden. Eur J Cancer. 2010;46(5):926-31.

78. Ayed Z, Houinato D, Hocine M, Ranger-Rogez S, Denis F. Prevalence of serum markers of hepatitis $B$ and $C$ in blood donors and pregnant women in Algeria. Bull Soc Pathol Exot. 1995;88(5):225-8.

79. National Travel Health Network, C., Country Information, Algeria, Tunisia Morocco, 2009.

80. Berkane S. French Luncheon comment prendre en charge les patients atteints d'hépatite $C$ avec les médicaments disponibles en Algérie, 2009.

81. Rouabhia S, Sadelaoud M, Chaabna-Mokrane K, Toumi W, Abenavoli L. Hepatitis C virus genotypes in north eastern Algeria: A retrospective study. World J Hepatol. 2013;5(7):393-7.

82. Saleh MG, Pereira LM, Tibbs CJ, Ziu M, al-Fituri MO, Williams R, McFarlane IG. High prevalence of hepatitis $C$ virus in the normal Libyan population. Trans R Soc Trop Med Hyg. 1994;88(3):292-4.

83. Daw MA, Elkaber MA, Drah AM, Werfalli MM, Mihat AA, Siala IM. Prevalence of hepatitis $C$ virus antibodies among different populations of relative and attributable risk. Saudi Med J. 2002;23(11):1356-60.

84. Elasifer HA, Agnnyia YM, Al-Alagi BA, Daw MA. Epidemiological manifestations of hepatitis $C$ virus genotypes and its association with potential risk factors among Libyan patients. Virol J. 2010;7(317):7-317.

85. Benjelloun S, Bahbouhi B, Sekkat S, Bennani A, Hda N, Benslimane A. AntiHCV seroprevalence and risk factors of hepatitis $C$ virus infection in Moroccan population groups. Res Virol J. 1996;147:247-55. 
86. Benouda A, Boujdiya Z, Ahid S, Abouqal R, Adnaoui M. Prevalence of hepatitis $C$ virus infection in Morocco and serological tests assessment of detection for the viremia prediction. Pathol Biol. 2009;57(5):368-72.

87. Lahlou Amine I, Zouhair S, Chegri M, L'kassmi H. Seroprevalence of anti-HCV in patients of the Military Hospital Moulay Ismail (Meknes, Morocco): Data analysis of the medical biology laboratory (2002-2005). Bull Soc Pathol Exot. 2010;103(4):255-8. [Article in French.

88. Boulaajaj K, Elomari Y, Elmaliki B, Madkouri B, Zaid D, Benchemsi N. Prevalence of hepatitis $C$, hepatitis B and HIV infection among haemodialysis patients in Ibn-Rochd university hospital, Casablanca]. Nephrol Ther. 2005;1(5):274-84.

89. Sekkat S, Kamal N, Benali B, Fellah H, Amazian K, Bourquia A, El Kholti A, Benslimane A. Prevalence of anti-HCV antibodies and seroconversion incidence in five haemodialysis units in Morocco. Nephrol Ther. 2008;4(2): 105-10. Article in French.

90. Bahadi A, Maoujoud O, Hassani K, Akhmouch I, Doblali T, El Allam M, et al. L'hépatite C virale en hémodialyse: étude multicentrique ambispective de séroconversion et de prévalene. Néphrologie Thérapeutique. 2011;7:399-406.

91. Trimbitas RD, Serghini FZ, Lazaar F, Baha W, Foullous A, Essalhi M, et al. The "hidden" epidemic: a snapshot of Moroccan intravenous drug users. Virol J. 2014;11(43):11-43.

92. Benani A, El-Turk J, Benjelloun S, Sekkat S, Nadifi S, Hda N, et al. HCV genotypes in Morocco. J Med Virol. 1997;52(4):396-8.

93. Hannachi N, Boughammoura L, Marzouk M, Tfifha M, Khlif A, Soussi S, et al. Viral infection risk in polytransfused adults: seroprevalence of seven viruses in central Tunisia. Bull Soc Pathol Exot. 2011;104(3):220-5.

94. Ben Alaya Bouafif N, Triki H, Mejri S, Bahri O, Chlif S, Bettaib J, et al. A case control study to assess risk factors for hepatitis $C$ among a general population in a highly endemic area of northwest Tunisia. Arch Inst Pasteur Tunis. 2007:84(1-4):21-7.

95. Mejri S, Mhalla S, Ben Yahia A, Triki H. Molecular and phylogenetic analyses of Tunisian hepatitis C virus strains subtype 1b. Ann Biol Clin. 2012;70(6): 707-16

96. Frank C, Mohamed MK, Strickland GT, Lavanchy D, Arthur RR, Magder LS, et al. The role of parenteral antischistosomal therapy in the spread of hepatitis C virus in Egypt. Lancet. 2000:355(9207):887-91.

97. El-Zanaty F. Egypt Demographic and Health Survey 2008. Cairo, Egypt: Ministry of Health, El-Zanaty and Associates and Macro International. 2009.

98. Mohamoud YA, Mumtaz GR, Riome S, Miller D, Abu-Raddad L. The epidemiology of hepatitis $C$ virus in Egypt: a systematic review and data synthesis. BMC Infect Dis. 2013;13:288-308.

99. DeWolfe Miller F, Abu-Raddad LJ. Evidence of intense ongoing endemic transmission of hepatitis C virus in Egypt. Proc Natl Acad Sci U S A. 2010; 107(33):14757-62.

100. Donato F, Boffetta P, Puoti M. A meta-analysis of epidemiological studies on the combined effect of hepatitis B and $C$ virus infections in causing hepatocellular carcinoma. Int J Cancer. 1998;75(3):347-54.

101. El-Zayadi AR, Badran HM, Barakat EM, Attia M-D, Shawky S, Mohamed MK, et al. Hepatocellular carcinoma in Egypt: a single center study over a decade. World J Gastroenterol. 2005;11:5193-8.

102. Forman D. Helicobacter pylori and gastric cancer. Scand J Gastroenterol Suppl. 1996;220:23-6.

103. Helicobacter and Cancer Collaborative Group. Gastric cancer and Helicobacter pylori: a combined analysis of 12 case control studies nested within prospective cohorts. Gut. 2001;49(3):347-53.

104. Alaoui Boukhris S, Benajah DA, El Rhazi K, Ibrahimi SA, Nejjari C, Amarti A, et al. Prevalence and distribution of Helicobacter pylori cagA and vacA genotypes in the Moroccan population with gastric disease. Eur J Clin Microbiol Infect Dis. 2012;31(8):1775-81.

105. Olama SM, El-Arman M. Helicobacter pylori in Egyptian patients with fibromyalgia syndrome. Egyptian Rheumatologist. 2013;35(3):167-73.

106. Mohammad MA, Hussein L, Coward A, Jackson SJ. Prevalence of Helicobacter pylori infection among Egyptian children: impact of social background and effect on growth. Public Health Nutr. 2008;11(3):230-6.

107. Mansour KB, Keita A, Zribi M, Masmoudi A, Zarrouk S, Labbene M, et al. Seroprevalence of Helicobacter pylori among Tunisian blood donors (outpatients), symptomatic patients and control subjects. Gastroenterol Clin Biol. 2010;34(1):75-82.

108. Siai K, Ghozzi M, Ezzine H, Medjahed N, Azzouz MM. Prevalence and risk factors of Helicobacter pylori infection in Tunisian children: 1055 children in Cap-Bon (northeastern Tunisia). Gastroenterol Clin Biol. 2008;32(11):881-6.
109. Sixième colloque sur Helocobacter Pylori, L.A.d.R.s.H.-A., Palais de la Culture Moufdi Zakaria, 20 Feb 2011

110. Mégraud F, Brassens-Rabbé MP, Denis F, Belbouri A, Hoa DQ. Seroepidemiology of Campylobacter pylori infection in various populations. J Clin Microbiol. 1989;27(8):1870-3.

111. Zhou X, Cui J, Macias V, Kajdacsy-Balla AA, Ye H, Wang J, Rao PN. The progress on genetic analysis of nasopharyngeal carcinoma. Comp Funct Genomics. 2007;57513(10):57513.

112. Chang ET, Adami HO. The enigmatic epidemiology of nasopharyngeal carcinoma. Cancer Epidemiol Biomarkers Prev. 2006;15(10):1765-77.

113. IARC, Lyon, France: World Health Organization. Epstein-Barr Virus and Kaposi's Sarcoma Herpesvirus/Human Herpesvirus 8. 1997.

114. Rickinson AB, Kieff E. Epstein-Barr Virus. Virology. 2007:5:2655-700.

115. Belbaraka R, Lalya I, Boulaamane L, Tazi M, Benjaafar N, Errihani H. Dietary risk factors of undifferenced nasopharyngeal carcinoma : a case-control study. Tunis Med. 2013;91(6):406-9.

116. Feng BJ, Jalbout M, Ayoub WB, Khyatti M, Dahmoul S, Ayad M, et al. Dietary risk factors for nasopharyngeal carcinoma in Maghrebian countries. Int J Cancer. 2007;121(7):1550-5.

117. El Kassimi B, Benchemsi N, Mikou O, El Ouazzani T, Lakhdar H. Maladie de Kaposi et anticorps anti-herpès virus-8 au Maroc. Med Mal Infect. 2003;33(4) 226-8.

118. Errihani H, Berrada N, Raissouni S, Rais F, Mrabti H, Rais G. Classic Kaposi's sarcoma in Morocco: clinico-epidemiological study at the National Institute of Oncology. BMC Dermatol. 2011;11:15-20.

119. Sodqi M, Marih L, Lahsen AO, Bensghir R, Chakib A, Himmich $\mathrm{H}$, et al. Causes of death among $91 \mathrm{HIV}$-infected adults in the era of potent antiretroviral therapy. Presse Med. 2012;41(7-8):e386-90.

120. Hannachi N, Ben Fredj N, Samoud S, Ferjani A, Khlif A, Boughammoura L, et al. Seroprevalence and risk factors of human herpes virus 8 infection in Central-East Tunisia. Pathol Biol. 2012;60(5):282-6.

121. Lahlaoui H, Niija H, Ben Moussa M. Seroprevalence of human herpesvirus 8 in kidney transplant recipients in a single-center study from Tunisia. Iran J Kidney Dis. 2012;6(1):14-6.

122. Harzallah K, Abderrahim E, Chareffedine K, Yeich S, Belhadj R, Skhiri H, et al. Cancers after renal transplantation: multicenter experience. Saudi J Kidney Dis Transpl. 2008:19(5):825-30.

123. Mseddi M, Marrekchi S, Abdelmaksoud W, Bouassida S, Meziou TJ, Boudaya $\mathrm{S}$, et al. Epidemio-clinical profile of skin cancer in southern Tunisia. Tunis Med. 2007:85(6):505-8

124. Dhrif AS, Kilani B, Ammari L, Kanoun F, Tiouri H, Ben CT. AIDS-associated Kaposi's sarcoma: 22 cases. Tunis Med. 2007:85(6):494-9.

125. Andreoni M, Sarmati L, Nicastri E, El Sawaf G, El Zalabani M, Uccella I, et al. Primary human herpesvirus 8 infection in immunocompetent children. JAMA. 2002;287(10):1295-300.

126. Blattner W, Takatsuki K, Gallo R. Human T-cell leukemia lymphoma virus and adult T-cell leukemia. JAMA. 1983;250:1074-80.

127. De-The G, Gessain A, Gazzolo L. Comparative seroepidemiology of HTLV-I and HTLV-II in the French West Indies and some African countries. Cancer Res. 1985:45(9):S4633-6.

\section{Submit your next manuscript to BioMed Central and we will help you at every step:}

- We accept pre-submission inquiries

- Our selector tool helps you to find the most relevant journal

- We provide round the clock customer support

- Convenient online submission

- Thorough peer review

- Inclusion in PubMed and all major indexing services

- Maximum visibility for your research

Submit your manuscript at www.biomedcentral.com/submit 